\title{
Substrate analogs that trap the 2'-phospho-ADP- ribosylated RNA intermediate of the Tpt1 (tRNA 2'-phosphotransferase) reaction pathway
}

\author{
SWATHI DANTULURI, ${ }^{1}$ LEONORA ABDULLAHU, ${ }^{2}$ ANNUM MUNIR, ${ }^{1}$ ADAM KATOLIK, ${ }^{2}$ MASAD J. DAMHA, ${ }^{2}$ \\ and STEWART SHUMAN ${ }^{1}$ \\ ${ }^{1}$ Molecular Biology Program, Sloan-Kettering Institute, New York, New York 10065, USA \\ ${ }^{2}$ Department of Chemistry, McGill University, Montreal, Quebec H3A0B8, Canada
}

\begin{abstract}
The enzyme Tpt1 removes an internal RNA $2^{\prime}-\mathrm{PO}_{4}$ via a two-step reaction in which: (i) the $2^{\prime}-\mathrm{PO}_{4}$ attacks $\mathrm{NAD}^{+}$to form an RNA-2'-phospho-(ADP-ribose) intermediate and nicotinamide; and (ii) transesterification of the ADP-ribose O2" to the RNA 2'-phosphodiester yields 2'-OH RNA and ADP-ribose-1",2"-cyclic phosphate. Because step 2 is much faster than step 1, the ADP-ribosylated RNA intermediate is virtually undetectable under normal circumstances. Here, by testing chemically modified nucleic acid substrates for activity with bacterial Tpt1 enzymes, we find that replacement of the ribose-2'- $\mathrm{PO}_{4}$ nucleotide with arabinose-2'-PO${ }_{4}$ selectively slows step 2 of the reaction pathway and results in the transient accumulation of high levels of the reaction intermediate. We report that replacing the NMN ribose of NAD ${ }^{+}$with $2^{\prime}$-fluoroarabinose (thereby eliminating the ribose O2" nucleophile) results in durable trapping of RNA-2'-phospho-(ADP-fluoroarabinose) as a "dead-end" product of step 1 . Tpt1 enzymes from diverse taxa differ in their capacity to use ara-2" F$\mathrm{NAD}^{+}$as a substrate.
\end{abstract}

Keywords: ADP-ribosylation; RNA 2'-phosphotransferase; nicotinamide adenine dinucleotide; transesterification

\section{INTRODUCTION}

tRNA 2'-phosphotransferase (Tpt1) is an essential enzyme in the fungal and plant tRNA splicing pathways that removes the $2^{\prime}-\mathrm{PO}_{4}$ at the splice junction generated by fungal and plant tRNA ligases (Culver et al. 1997). Tpt1 catalyzes a two-step reaction whereby: (i) the internal RNA $2^{\prime}-\mathrm{PO}_{4}$ attacks NAD ${ }^{+}$to form an RNA-2'-phospho-(ADP-ribose) intermediate; and (ii) transesterification of the ribose $\mathrm{O} 2^{\prime \prime}$ to the 2'-phosphodiester yields 2'-OH RNA and ADP-ribose1",2"-cyclic phosphate (Supplemental Fig. S1; McCraith and Phizicky 1991; Culver et al. 1993; Spinelli et al. 1999; Steiger et al. 2005; Munir et al. 2018a). Whereas Tpt1 homologs with verified RNA 2'-phosphotransferase activity in vitro and in vivo are present in taxa other than fungi and plants (Spinelli et al. 1998; Sawaya et al. 2005; Munir et al. 2018a,b), their roles and their potential endogenous substrates in these taxa (bacteria, metazoa, and archaea) are unknown. Some Tpt1 orthologs catalyze additional $\mathrm{NAD}^{+}$-dependent ADP-ribosyltransferase reactions-

Corresponding authors: s-shuman@ski.mskcc.org, masad.damha@mcgill.ca

Article is online at http://www.rnajournal.org/cgi/doi/10.1261/rna. 074377.119. such as ADP-ribose capping of RNA and DNA 5'-phosphate ends (Munir et al. 2018b) and removal of nucleic acid 2' or 3' terminal monophosphates (Munir et al. 2019) -albeit less vigorously than the canonical internal RNA 2 '-phosphate removal reaction. Such findings raise interesting questions about Tpt1 substrate recognition and how it might vary among taxa.

Renewed interest in Tpt1 is prompted by its candidacy as a target for discovery of anti-fungal drugs, which is based on the fact that the enzymatic mechanism of tRNA splicing in metazoa-mediated by the RNA ligase RtcBis entirely different from that of fungi and does not result in a junction $2^{\prime}-\mathrm{PO}_{4}$ (Popow et al. 2012). Whereas mammals do have a homolog of Tpt1, it plays no essential role in mammalian physiology, insofar as a homozygous tpt1-KO mouse is viable, develops normally, and has no defects in protein synthesis (Harding et al. 2008). This is in contrast to fungi, where Tpt1 is essential for viability

(C) 2020 Dantuluri et al. This article is distributed exclusively by the RNA Society for the first 12 months after the full-issue publication date (see http://rnajournal.cshlp.org/site/misc/terms.xhtml). After 12 months, it is available under a Creative Commons License (Attribution-NonCommercial 4.0 International), as described at http:// creativecommons.org/licenses/by-nc/4.0/. 
in the model fungi Saccharomyces cerevisiae and Schizosaccharomyces pombe and in the pathogenic fungus Candida albicans (Segal et al. 2018).

One can envision two ways to interdict Tpt1 activity: (i) by inhibiting transfer of ADP-ribose from NAD ${ }^{+}$to $2^{\prime}$ $\mathrm{PO}_{4}$ RNA, thereby resulting in the accumulation of spliced tRNAs that retain the $2^{\prime}-\mathrm{PO}_{4}$ in the anticodon loop; or (ii) by inhibiting the transesterification step and trapping the ADP-ribosylated RNA intermediate, thereby generating tRNAs with bulky lesions in the anticodon loop. Valuable insights into substrate recognition and the mechanism of the transesterification step emerged from a crystal structure of Clostridium thermocellum Tpt1 in a product-mimetic complex with ADP-ribose-1" $-\mathrm{PO}_{4}$ in the $\mathrm{NAD}^{+}$site and pAp in the RNA site (Banerjee et al. 2019) and from kinetic and mutational analyses of Runella slithyformis Tpt1 that identified a Arg-His-Arg-Arg catalytic tetrad in the active site and pinpointed one of the arginines as specifically essential for step 2 of the Tpt1 pathway (Munir et al. 2018a). Mutating this arginine slowed the step 1 rate by only threefold while slowing the step 2 rate by a factor of 214 , thus resulting in the transient accumulation of very high levels of the normally evanescent ADP-ribosylated RNA intermediate.

Having created a situation in which the intermediate can be trapped by mutating the Tpt1 enzyme, we sought in the present study to achieve a similar outcome by chemical modifications of the $\mathrm{NAD}^{+}$and $2^{\prime}-\mathrm{PO}_{4}$ RNA substrates. Our results highlight that replacement of the RNA ribose-2' $-\mathrm{PO}_{4}$ nucleotide with arabinose- $2^{\prime}-\mathrm{PO}_{4}$ and substitution of the NMN ribose of $\mathrm{NAD}^{+}$with $2^{\prime}$-fluoroarabinose result in transient and permanent trapping of the Tpt1 reaction intermediate, respectively.

\section{RESULTS AND DISCUSSION}

\section{Utilization of ara-2"-fluoro NAD ${ }^{+}$by Tpt1 enzymes traps the ADP-ribosylated RNA}

The ara-2"F analog of $\mathrm{NAD}^{+}$(shown in Fig. 1A) could, in principle, be able to support the first step in the Tpt1 pathway, but would be unable to undergo transesterification in the second step for lack of an $\mathrm{O} 2^{\prime \prime}$ nucleophile. Because the effect of an arabinose sugar in lieu of ribose on the nicotinamide nucleoside moiety of $\mathrm{NAD}^{+}$on substrate utilization by Tpt1 had not been queried previously, we surveyed four different Tpt1 enzymes (each at $0.5 \mu \mathrm{M}$ concentration) for activity in the presence of $0.2 \mu \mathrm{M} \mathrm{5}{ }^{\prime 2} \mathrm{P}$-labeled 6-mer 2'- $\mathrm{PO}_{4}$-branched RNA oligonucleotide (shown in Fig. 1B) and either $50 \mu \mathrm{M} \mathrm{NAD}{ }^{+}$or ara- $2^{\prime \prime} F-N A D^{+}$. The Tpt1 proteins were from Runella slithyformis (a bacterium), Clostridium thermocellum (a bacterium), Chaetomium thermophilum (a fungus), and Homo sapiens (human). After a $30 \mathrm{~min}$ incubation at $37^{\circ} \mathrm{C}$, the reaction products were resolved by urea-PAGE and visualized by autoradiog- raphy (Fig. 1A). Control reactions showed that each of the Tpt1 enzymes converted all of the input $2^{\prime}-\mathrm{PO}_{4}$ RNA substrate to a slower-migrating 2'-OH RNA product in the presence of $50 \mu \mathrm{M} \mathrm{NAD}{ }^{+}$. When provided with $50 \mu \mathrm{M}$ ara-2"F-NAD ${ }^{+}$, the Runella and Clostridium enzymes converted nearly all of the substrate into an even more slowly migrating species that corresponds to an ADP-ribosylated RNA (Munir et al. 2018a), which in this case is an RNA-2'phospho-(ADP-fluoroarabinose) dead-end product of step 1 of the Tpt1 pathway (Fig. 1A). Chaetomium Tpt1 also formed the dead-end product in the presence of $50 \mu \mathrm{M}$ ara- $2^{\prime \prime} \mathrm{F}-\mathrm{NAD}{ }^{+}$, though the extent of substrate conversion was lower. In contrast, human Tpt1 effected no detectable reaction of the $2^{\prime}-\mathrm{PO}_{4}$ RNA substrate in the presence of $50 \mu \mathrm{M}$ ara-2"F-NAD ${ }^{+}$(Fig. 1). We surmise that Tpt1 enzymes from different sources may vary in their sensitivity to the arabinose sugar modification of $\mathrm{NAD}^{+}$, but the utilization of ara- $2^{\prime \prime}$ F-NAD ${ }^{+}$as a substrate by Tpt1 does indeed result in trapping of the step 1 reaction product.

The temporal profiles of the reactions of Runella, Clostridium, and Chaetomium Tpt1 $(0.5 \mu \mathrm{M})$ with $2^{\prime}-\mathrm{PO}_{4}$ RNA substrate $(0.2 \mu \mathrm{M})$ and $50 \mu \mathrm{M}$ ara-2"F-NAD ${ }^{+}$are shown in Figure 1B. The data revealed a kinetic hierarchy whereby the apparent rate constant of the Clostridium enzyme for transfer of ADP-fluoroarabinose to the RNA 2'phosphate $\left(0.40 \pm 0.022 \mathrm{~min}^{-1}\right)$ was fivefold faster than that of Runella Tpt1 $\left(0.077 \pm 0.0062 \mathrm{~min}^{-1}\right)$ and 16-fold faster than Chaetomium Tpt1 $\left(0.025 \pm 0.0028 \mathrm{~min}^{-1}\right)$.

Although the yield of 2'-phospho-(ADP-fluoroarabinose) 6-mer RNA was high for Runella and Clostridium Tpt1, the apparent step 1 rate constant of Runella Tpt1 with $50 \mu \mathrm{M}$ ara-2"F-NAD ${ }^{+}$was at least two orders of magnitude slower than the step 1 rate constant observed with $1 \mathrm{mM} \mathrm{NAD}^{+}$ (Munir et al. 2018a). Clues to the slowing effect of the ara- $2^{\prime \prime} \mathrm{F}$ modification were gleaned by inspection of the crystal structure of Clostridium Tpt1 in complex with ADP-ribose-1" $-\mathrm{PO}_{4}$, a derivative of the ADP-ribose-1" $2^{\prime \prime}-$ cyclic- $\mathrm{PO}_{4}$ reaction product that had undergone cyclic phosphate hydrolysis in situ (Fig. 1C; Banerjee et al. 2019). The ADP-ribose moiety occupies the $\mathrm{NAD}^{+}$substrate site in the carboxy-terminal lobe of the Tpt1 tertiary structure and the $1^{\prime \prime}-\mathrm{PO}_{4}$ moiety is the $\alpha$ anomer, consistent with stereochemical inversion at the nicotinamide ribose $\mathrm{C} 1$ of $\beta-\mathrm{NAD}^{+}$during step1 of the Tpt1 pathway. The ribose O2" receives a hydrogen bond from Lys66, a residue conserved among Tpt1 family enzymes; Lys66 also makes a hydrogen bond to the $1^{\prime \prime}-\mathrm{PO}_{4}$ (Fig. 1C). The ribose C2 atom makes van der Waals contact to the nearby Arg139 side chain (conserved among Tpt1 family enzymes) that engages the $\alpha$ and $\beta$ phosphates of ADP-ribose/NAD ${ }^{+}$(Fig. 1C). By superimposing a structure of ara$2^{\prime} \mathrm{F}$ (extracted from the ara-2'F-ADPR ligand in the $1.75 \AA$ crystal structure of human CDC38; Liu et al. 2009) on the ribose of $A D P$-ribose- $1^{\prime \prime}-\mathrm{PO}_{4}$ in the Tpt1 complex, we 


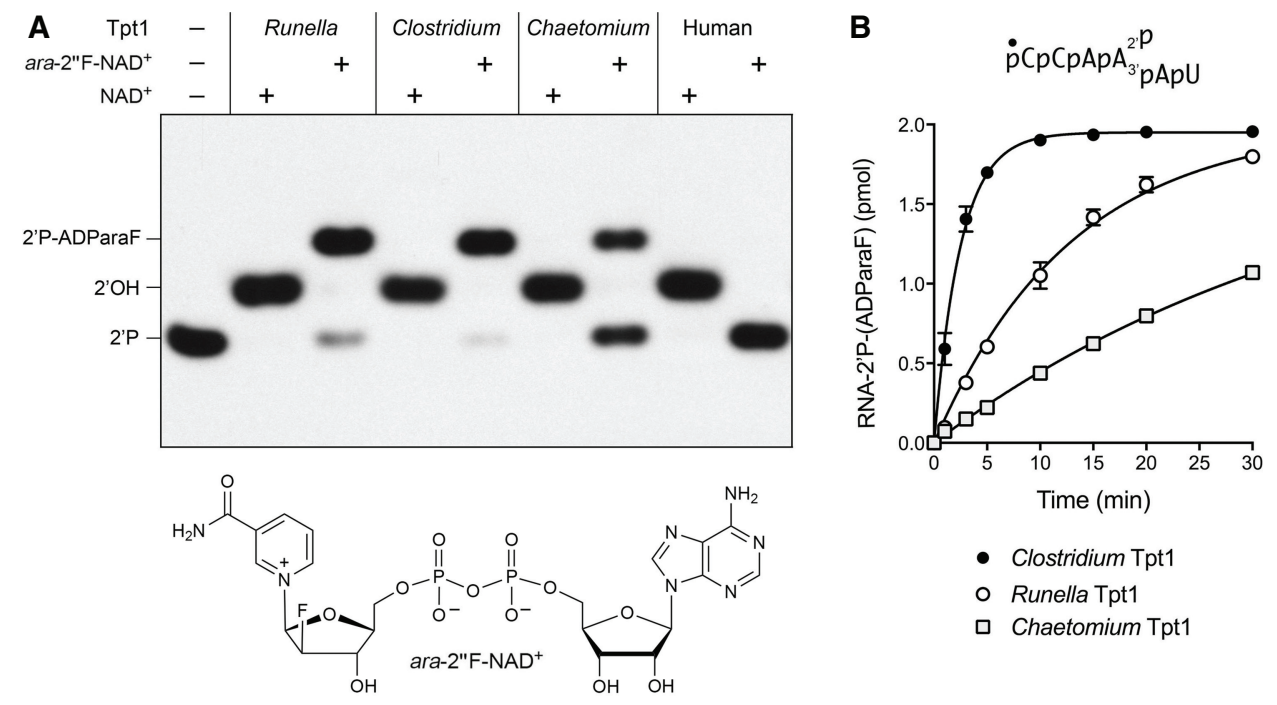

C

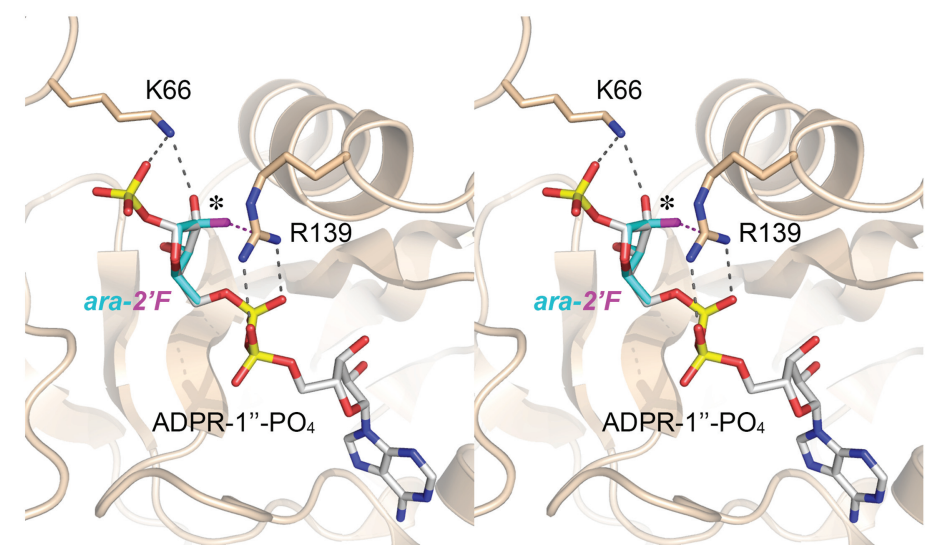

FIGURE 1. Utilization of ara-2"-fluoro NAD ${ }^{+}$by Tpt1 enzymes traps the ADP-ribosylated RNA. (A) Tpt1 reaction mixtures $(10 \mu \mathrm{L})$ containing 100

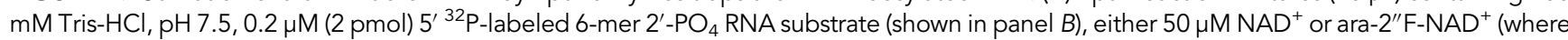
indicated by + ), and $0.5 \mu \mathrm{M}(5 \mathrm{pmol})$ Runella slithyformis, Clostridium thermocellum, Chaetomium themophilum, or human Tpt1 were incubated at $37^{\circ} \mathrm{C}$ for $30 \mathrm{~min}$. The products were analyzed by urea-PAGE and visualized by autoradiography. The identities of the radiolabeled RNAs are indicated on the left. The chemical structure of ara-2" $\mathrm{F}-N A D^{+}$is shown at bottom. (B) Reaction mixtures $(100 \mu \mathrm{L}) \mathrm{containing} 100 \mathrm{mM} \mathrm{Tris-} \mathrm{HCl}, \mathrm{pH}$ 7.5, $50 \mu \mathrm{M}$ ara-2" F-NAD ${ }^{+}, 0.2 \mu \mathrm{M} \mathrm{5^{ \prime }}{ }^{32} \mathrm{P}-$ labeled 6-mer 2'-PO 4 substrate, and $1 \mu \mathrm{M}$ Clostridium, Runella, or Chaetomium Tpt1 were incubated at $37^{\circ} \mathrm{C}$. Aliquots $(10 \mu \mathrm{L}$, containing 2 pmol of RNA) were withdrawn at the times specified and quenched immediately with three volumes of cold $90 \%$ formamide, $50 \mathrm{mM}$ EDTA. The reaction products were analyzed by urea-PAGE and quantified by scanning the gels. The extents of formation of the RNA-2'P-(ADParaF) product are plotted as a function of reaction time. Each datum is the average of three independent time-course experiments $( \pm$ SEM). The data were fit to a one-phase association model in Prism. (C) Stereo view of the structure of Clostridium Tpt1 (beige cartoon trace) in complex with ADPR-1"- $-\mathrm{PO}_{4}$ (stick model with gray carbons) in the NAD site (from pdb 6E3A). The figure highlights atomic contacts of Lys 66 with the ADP-ribose-O2' and Arg139 with the alpha and beta phosphates of ADPR/NAD (denoted by black dashed lines). A structure of ara-2' $\mathrm{F}$ (stick model with cyan carbon and magenta fluorine atoms; excerpted from pdb 3I9M) is superimposed on the ribose of ADPR-1"-PO ${ }_{4}$. The asterisk denotes the opposite orientations of the ribose hydroxyl and arabinose fluorine substituents. Close contact (2.7 $\AA$ ) of the modeled $2^{\prime} F$ with Arg139 is indicated by the magenta dashed line.

can see the "up" configuration of the ara-2'F moiety versus the "down" conformation of the ribose-2'OH (highlighted by the asterisk in Fig. 1C). In addition to eliminating the Lys66 contact to the NAD ${ }^{+}$substrate, the ara-2'F modification introduces a steric clash between the $2^{\prime} \mathrm{F}$ atom and the Arg139 side chain. Note that the equivalent of Arg139 in Runella Tpt1 (Arg137) is critical for its RNA 2'-phosphotransferase activity in vitro and in vivo, as gauged by the effect of its replacement with alanine (Banerjee et al. 2019). We envision that the structural changes modeled in Figure
$1 \mathrm{C}$ account, at least in part, for the slowing of the Tpt1 step 1 reaction with ara-2" F-NAD ${ }^{+}$.

\section{Runella Tpt1 efficiently removes an internal 2 '-phosphate from a DNA substrate}

Previous studies of RNA repair enzymes that modify or join RNA ends have underscored the theme that their "RNA specificity" is dictated by a requirement for ribose at only a limited number of nucleotide positions within their 
polynucleotide substrates, as gauged by the ability to replace many or most of the ribonucleotides with deoxyribonucleotides. For example, the RNA specificity of the RNA nick-sealing enzyme T4 RNA ligase 2 arises from a requirement for at least two ribonucleotides immediately flanking the $3^{\prime}-\mathrm{OH}$ of the nick; the rest of the nicked duplex can be replaced by DNA (Nandakumar and Shuman 2004). In the case of the plant tRNA ligase AtRNL, which acts via the same chemical pathway of healing and sealing as fungal tRNA ligase $\mathrm{Trl} 1$, a single ribonucleoside-2', $3^{\prime}$-cyclic- $\mathrm{PO}_{4}$ moiety enables AtRNL to efficiently splice an otherwise all-DNA strand (Remus and Shuman 2014). Clostridium thermocellum Hen1 (CthHen1) is an RNA ribose-2'-Omethyltransferase that marks the $3^{\prime}$ terminal nucleoside of broken RNAs and protects ligated repair junctions from iterative damage by transesterifying endonucleases (Chan et al. 2009). CthHen 1 is adept at methylating a polynucleotide composed of 23 deoxyribonucleotides and one $3^{\prime}$ terminal ribonucleotide, signifying that it has no strict RNA specificity beyond the $3^{\prime}$ nucleoside (Jain and Shuman 2011).

To query the extent of the RNA requirement for Tpt1, we synthesized and then $5^{\prime 32} \mathrm{P}$-labeled an analog of the 6-mer $2^{\prime}-\mathrm{PO}_{4}$ oligonucleotide substrate in which the five nucleotides flanking the $2^{\prime}-\mathrm{PO}_{4}$ branched ribonucleotide were replaced by deoxynucleotides (Fig. 2). The $2 '-\mathrm{PO}_{4} \mathrm{RNA}$ and DNA substrates (at $0.2 \mu \mathrm{M}$ concentration) were reacted for 30 min with increasing amounts of Runella Tpt1 in the presence of $1 \mathrm{mM} \mathrm{NAD}^{+}$. The product distributions were quantified and are plotted as a function of input RslTpt1 (Fig. $2 \mathrm{~A}, \mathrm{~B})$. The salient points were that Runella Tpt1 is virtually equally adept at removing an internal $2^{\prime}-\mathrm{PO}_{4}$ from RNA and DNA polynucleotides, without accumulating significant amounts of the 2'-phospho-ADP-ribosylated intermediate at limiting enzyme concentrations.

\section{Effect of 2'F-arabinose sugars flanking the 2'-phosphate branchpoint}

Arabinonucleic acid (ANA) is the $C 2^{\prime}$-epimer of RNA in which the chirality of the $2^{\prime}$ position of the pentose sugar is switched so that the $\mathrm{C}^{\prime}-\mathrm{OH}$ group points up, that is, in the direction opposite that of the $2^{\prime}$ hydroxyl of a ribose. $2^{\prime}$-Fluoroarabinonucleic acid (2'-FANA) is the C2'-F analog of ANA, in which the sugar pucker mimics that of DNA (Martín-Pintado et al. 2012). We tested Runella Tpt1 activity on a 2'-FANA version of the 6-mer $2^{\prime}-\mathrm{PO}_{4}$ oligonucleotide substrate in which the five nucleotides flanking the 2 ' $-\mathrm{PO}_{4}$ branched ribonucleotide were replaced by 2 'fluoro-arabinonucleotides. RslTpt1 removed the $2^{\prime}-\mathrm{PO}_{4}$ from the 2'-FANA substrate, albeit with approximately sevenfold lower specific activity compared to the 6-mer $2^{\prime}-\mathrm{PO}_{4}$ RNA control substrate (Fig. 3A,B). The 2'-phospho-ADP-ribosylated intermediate accumulated to an extent of $4 \%$ of total labeled RNA at low enzyme concentrations (Fig. 3B). Thus, RsITpt1 activity is tolerant of DNA in lieu of RNA adjacent to the $2^{\prime}-\mathrm{PO}_{4}$ branch but is less tolerant of a $2^{\prime}$-FANA nucleic acid.

\section{Effect of $3^{\prime}-5^{\prime}$ phosphorothioates flanking the 2'-phosphate branchpoint}

Phosphorothioate (PS) modifications of the $3^{\prime}-5^{\prime}$ phosphodiester backbone of DNA and 2'-FANA oligonucleotides provide stability against nuclease digestion while allowing for RNase H-mediated cleavage of complementary RNAs (Damha et al. 1998; Wilds and Damha 2000). As such, PSDNA and PS-2'-FANA oligos are effective tools for antisense interference manipulations of gene expression in vivo (Kalota et al. 2006). Here we introduced racemic PS modifications at all five $3^{\prime}-5^{\prime}$ phosphodiesters of the
A
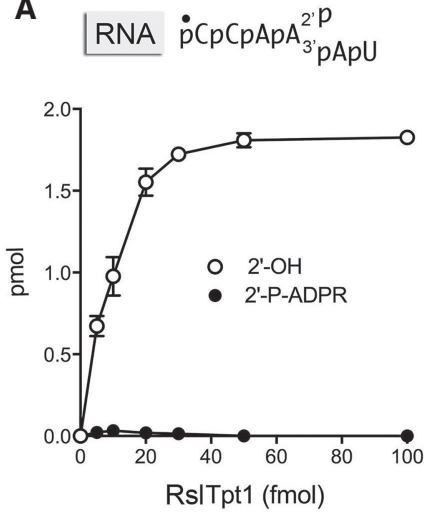

B
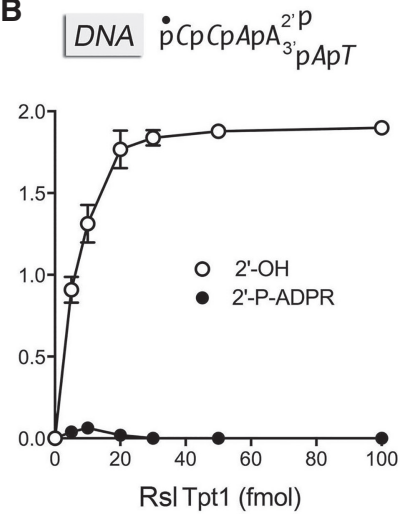

C

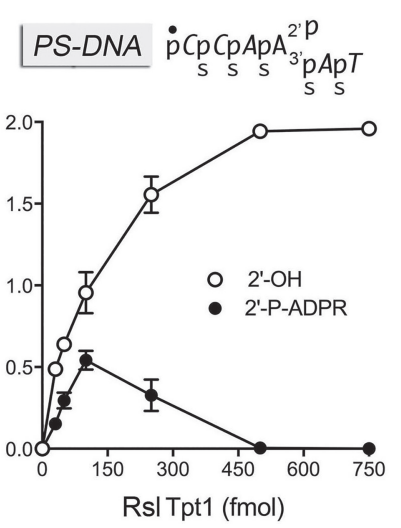

FIGURE 2. Runella Tpt1 efficiently removes an internal DNA 2'-phosphate. Reaction mixtures $(10 \mu \mathrm{L})$ containing $100 \mathrm{mM} \mathrm{Tris-HCl,} \mathrm{pH} \mathrm{7.5,} 1 \mathrm{mM}$ $\mathrm{NAD}^{+}, 0.2 \mu \mathrm{M}(2 \mathrm{pmol}) 5^{\prime}{ }^{32} \mathrm{P}$-labeled 6-mer 2-PO $\mathrm{PO}_{4} \mathrm{RNA}(A)$, DNA ( $B$, with deoxyribonucleotides in italics), or PS-DNA ( $C$, with deoxyribonucleotides in italics) substrates, and Runella Tpt1 as specified were incubated at $37^{\circ} \mathrm{C}$ for $30 \mathrm{~min}$. The reaction products were analyzed by urea-PAGE. The extents of formation of the $2^{\prime}-\mathrm{OH}$ product and the ADP-ribosylated intermediate are plotted as a function of input RslTpt 1 . Each datum is the average of three independent titration experiments \pm SEM. 

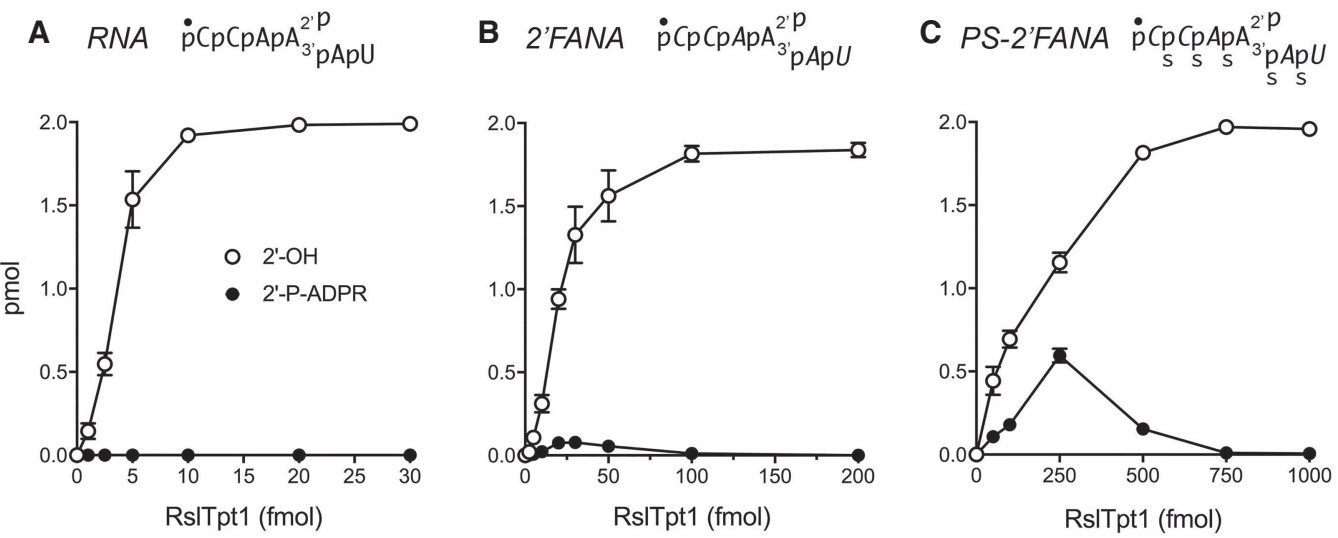

FIGURE 3. Effect of $2^{\prime} \mathrm{F}$-arabinose sugars flanking the $2^{\prime}$-phosphate branchpoint. Reaction mixtures $(10 \mu \mathrm{L})$ containing $100 \mathrm{mM} \mathrm{Tris-HCl}$, pH 7.5, $1 \mathrm{mM} \mathrm{NAD}^{+}, 0.2 \mu \mathrm{M}(2 \mathrm{pmol}) 5^{\prime}{ }^{32} \mathrm{P}$-labeled 6-mer 2'-PO 4 RNA (A), 2'FANA (B, with 2'-fluoroarabinonucleotides in italics), or PS-2'FANA (C, with $2^{\prime}$-fluoroarabinonucleotides in italics) substrates, and Runella Tpt 1 as specified were incubated at $37^{\circ} \mathrm{C}$ for 30 min. The reaction products were analyzed by urea-PAGE. The extents of formation of the 2 '-OH product and the ADP-ribosylated intermediate are plotted as a function of input RsITpt1. Each datum is the average of three independent titration experiments \pm SEM.

6-mer 2'-PO ${ }_{4}$ DNA and 2'-FANA substrates (creating in each case a mixture of 32 PS isomers) and tested them for activity with Runella Tpt1. These PS-modified 2'-PO oligos could be completely converted to 2'-OH products (Figs. 2C, 3C). However, the enzyme titration curves were shifted significantly to the right vis-à-vis the DNA and 2'-FANA substrates with unmodified phosphodiester backbones (Figs. 2B, 3B). Runella Tpt1 specific activity was reduced by 11-fold and sevenfold, respectively, by the PS modifications of DNA and 2'-FANA substrates. Moreover, there was substantial accumulation of the 2'-phosphoADP-ribosylated intermediate at sub-saturating enzyme levels, to an extent of $27 \%$ and $30 \%$ of total nucleic acid for the PS-DNA and PS-2'-FANA substrates, respectively (Figs. 2C, 3C).

\section{Effect of an arabinose sugar at the $2^{\prime}$-phosphate branchpoint}

We synthesized a 6-mer RNA with an internal arabinose-2' phosphate moiety (shown in Fig. 4D). A 30 min reaction of $0.2 \mu \mathrm{M}(2 \mathrm{pmol}) 5^{\prime}{ }^{32} \mathrm{P}$-labeled ara-2'- $\mathrm{PO}_{4}$ RNA with increasing concentrations of Runella Tpt1 in the presence of $1 \mathrm{mM} \mathrm{NAD}^{+}$resulted in the initial accumulation of very high levels of 2'-phospho-ADP-ribosylated intermediate, to a peak level of $70 \%$ of total RNA at 0.05 to $0.1 \mu \mathrm{M}$ RsITpt1 (0.5 to 1 pmol), followed by its progressive conversion to 2'-OH product as enzyme concentration was increased up to $1 \mu \mathrm{M}$ (10 pmol) (Fig. 4A). A kinetic analysis of the reaction under conditions of enzyme excess $(0.2$ $\mu \mathrm{M}$ ara-2' $-\mathrm{PO}_{4}$ RNA; $1 \mu \mathrm{M}$ RsITpt1) is shown in Figure 4B and revealed a precursor-product relationship whereby the ADP-ribosylated RNA intermediate accumulated steadily at early times and comprised $61 \%$ of total RNA at $1.5 \mathrm{~min}$ before declining steadily thereafter as all of the RNA was converted to 2'-OH product. The data fit well by nonlinear regression in Prism to a unidirectional two-step mechanism with apparent step 1 and step 2 rate constants of $1.50 \pm 0.07 \mathrm{~min}^{-1}$ and $0.35 \pm 0.01$ $\mathrm{min}^{-1}$, respectively. Comparison of these data to reaction rates of Runella Tpt1 with the 6-mer ribose-2'- $-\mathrm{PO}_{4} \mathrm{RNA}$ (step 1 and step 2 rate constants of $21 \mathrm{~min}^{-1}$ and 221 $\mathrm{min}^{-1}$, respectively; Munir et al. 2018a) highlights the profound impact of an arabinose sugar at the $2^{\prime}-\mathrm{PO}_{4}$ branchpoint, which slows step 1 by a factor of 14 but exerts a much stronger 630-fold effect on step 2.

Because we do not yet have a structure of a Tpt1 enzyme in complex with an RNA containing a 2'-phosphate, we are unable to convincingly model how the arabinose- $2^{\prime}-\mathrm{PO}_{4}$ modification affects substrate binding and reaction chemistry. However, we can guess from the available Tpt1 structure with product-mimetic ligands that the extensive network of electrostatic interactions of essential Tpt1 amino acid side chains with the transferred phosphate moiety (Banerjee et al. 2019) would be perturbed if the 2'-phosphate were oriented "up" from the arabinose sugar instead of down from ribose. We predict this would misalign the 2'-phosphate nucleophile with respect to the ribose C1" atom of $\mathrm{NAD}^{+}$and the departing nicotinamide during step 1 catalysis. From the rate effects, we suspect that an "up" conformation of the arabinose-2'-phosphodiester to ADP-ribose even more severely misaligns the geometry of the ADP-ribose O2" nucleophile and the RNA arabinose $\mathrm{O} 2$ ' leaving group during step 2 catalysis.

\section{Additive effect of an arabinose-2'-phosphate and the Runella Tpt1 R64A mutation}

Runella Tpt1 amino acids Arg16, His17, Arg64, and Arg119 are conserved in all Tpt1 homologs and essential 

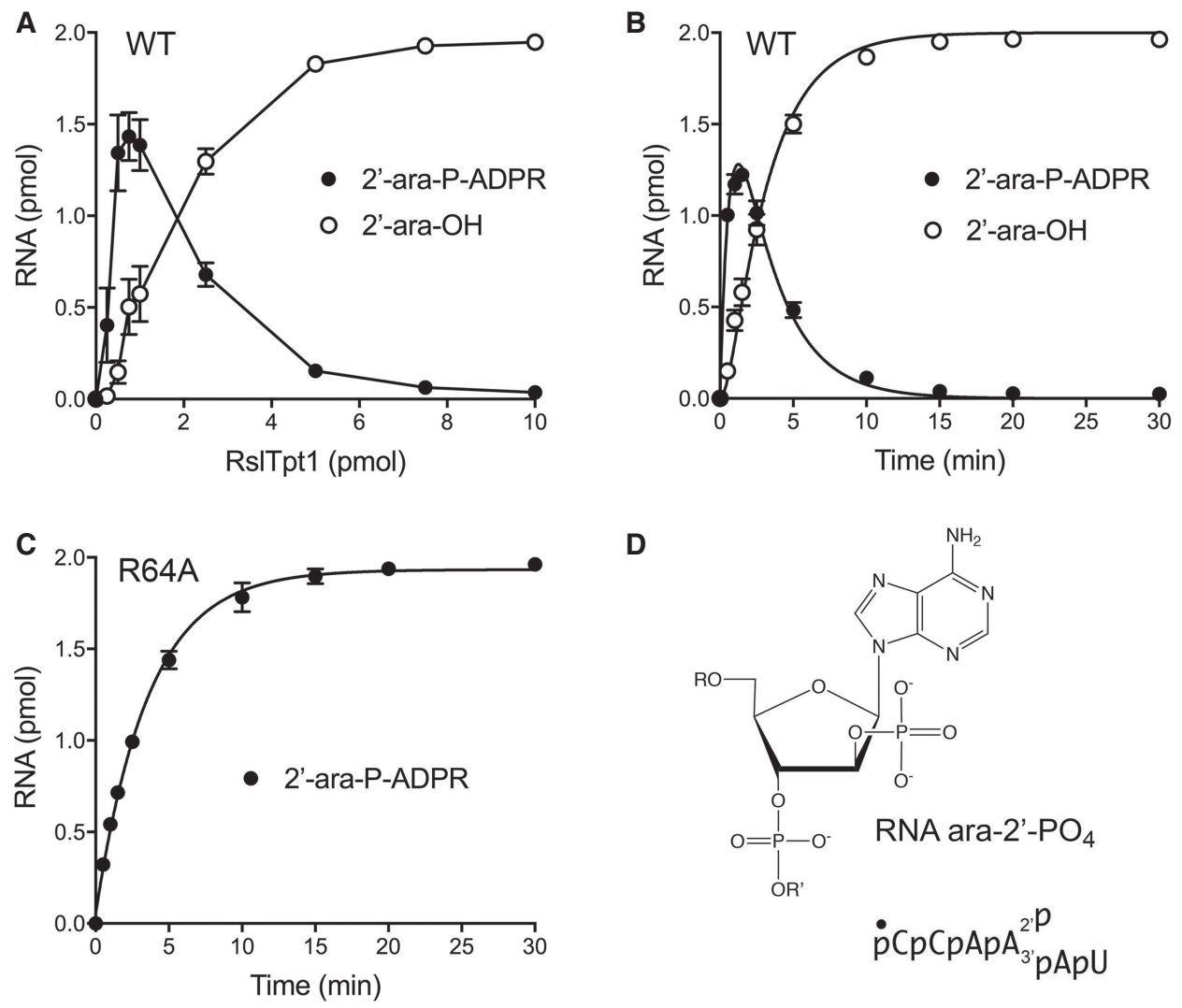

FIGURE 4. Effect of an arabinose sugar at the 2'-phosphate branchpoint. (A) Reaction mixtures $(10 \mu \mathrm{L})$ containing $100 \mathrm{mM} \mathrm{Tris-HCl,} \mathrm{pH} 7.5,1 \mathrm{mM}$ $\mathrm{NAD}^{+}, 0.2 \mu \mathrm{M}(2 \mathrm{pmol}) 5^{\prime}{ }^{32} \mathrm{P}$-labeled 6-mer ara-2'-PO 4 substrate (shown in D), and 0, 0.25, 0.5, 0.75, 1, 2.5, 5, 7.5, or 10 pmol wild-type RsITpt1 were incubated at $37^{\circ} \mathrm{C}$ for $30 \mathrm{~min}$. (B,C) Reaction mixtures $(100 \mu \mathrm{L})$ containing $100 \mathrm{mM}$ Tris- $\mathrm{HCl}, \mathrm{pH} 7.5,1 \mathrm{mM} \mathrm{NAD}{ }^{+}, 0.2 \mu \mathrm{M} \mathrm{5}{ }^{\prime 32} \mathrm{P}-$ labeled 6mer ara- $2^{\prime}-\mathrm{PO}_{4}$ substrate, and $1 \mu \mathrm{M}$ wild-type RsITpt1 $(B)$ or RsITpt1-R64A $(C)$ were incubated at $37^{\circ} \mathrm{C}$. The reactions were initiated by adding enzyme to a prewarmed reaction mixture. Aliquots ( $10 \mu \mathrm{L}$, containing 2 pmol of RNA) were withdrawn at the times specified and quenched immediately with 3 volumes of cold $90 \%$ formamide, 50 mM EDTA. The reaction products were analyzed by urea-PAGE and quantified by scanning the gels. The extents of formation of the 2'-OH product and the ADP-ribosylated intermediate are plotted as a function of input Rs ITpt1 (panel A) or reaction time (panels $B, C$ ). Each datum is the average of three independent titration or time-course experiments $( \pm S E M)$. (D) Chemical structure of the arabinose-2'- $-\mathrm{PO}_{4}$ branchpoint.

for activity (Munir et al. 2018a). Kinetic analysis of Runella Tpt1 alanine mutants implicated Arg64 and Arg16 as catalysts of the transesterification step. The Clostridium Tpt1 structure showed that the equivalent two arginines make bidentate contacts to the transferred $2^{\prime}-\mathrm{PO}_{4}$ in the ADP-ribose- 1 " $-\mathrm{PO}_{4}$ product ligand, consistent with the arginines stabilizing the transition state of the transesterification step. Whereas R16A mutation of Runella Tpt1 also profoundly affects step 1 of the pathway, the R64A mutation is highly selective in its effect on step 2, leading to transient accumulation of very high levels of the ADP-ribosylated intermediate (Munir et al. 2018a). Because the R64A effect resembles that of the arabinose- 2 ' $-\mathrm{PO}_{4}$ modification, we tested the reaction of the R64A mutant with the ara-2'$\mathrm{PO}_{4}$ RNA substrate (Fig. 4C). We found that RsITpt1R64A catalyzed quantitative conversion of the ara-2'- $-\mathrm{PO}_{4}$ substrate to 2'-phospho-ADP-ribosylated RNA over a 30 min time course with an apparent rate constant of $0.28 \pm 0.013 \mathrm{~min}^{-1}$. There was no detectable formation of a 2'-OH product. The rate constant of the R64A mutant for transfer of ADP-ribose to the arabinose-2'-phosphate was fivefold slower than that of wild-type Runella Tpt1. The effect of the R64A mutation on step 1 catalysis at the arabinose-2'-phosphate was similar to the threefold rate decrement in step 1 catalysis by the R64A mutant at a ribose-2'-phosphate (Munir et al. 2018a).

\section{Effect of an arabinose-2'-phosphate on Clostridium Tpt1}

To see if the intermediate-trapping effect of the ara-2'- $\mathrm{PO}_{4}$ modification extends to another Tpt1 ortholog, we performed a $30 \mathrm{~min}$ reaction of $0.2 \mu \mathrm{M}(2 \mathrm{pmol}) 5^{\prime}{ }^{32} \mathrm{P}$-labeled ara- $2^{\prime}-\mathrm{PO}_{4} \mathrm{RNA}$ and $1 \mathrm{mM} \mathrm{NAD}{ }^{+}$with increasing concentrations of Clostridium thermocellum Tpt1. This resulted in an initial accumulation of 2'-phospho-ADP-ribosylated intermediate, to a peak level of $65 \%$ of total RNA at $0.1 \mu \mathrm{M}$ CthTpt1 (1 pmol), followed by its progressive 
conversion to 2'-OH RNA product as enzyme concentration was increased up to $1 \mu \mathrm{M}(10 \mathrm{pmol})$, at which point the intermediate and product comprised $12 \%$ and $88 \%$ of total RNA, respectively (Fig. 5A). The residual intermediate was not diminished when the input enzyme was increased to $0.3 \mu \mathrm{M}$ (30 pmol) (Fig. 5A). A kinetic analysis of the reaction in enzyme excess $\left(0.2 \mu \mathrm{M}\right.$ ara- $2^{\prime}-\mathrm{PO}_{4}$ $\mathrm{RNA} ; 1 \mu \mathrm{M}$ CthTpt 1 ) showed accumulation of the intermediate at early times to an extent of $85 \%$ of total RNA at 1.5 min before its conversion thereafter to $2^{\prime}-\mathrm{OH}$ product (Fig. 5B). The apparent step 1 and step 2 rate constants were $2.19 \pm 0.16 \mathrm{~min}^{-1}$ and $0.060 \pm 0.0018 \mathrm{~min}^{-1}$, respectively (Fig. 5B). Thus, the rate of step 2 transesterification at an arabinose-2'- $-\mathrm{PO}_{4}$ was 37 -fold slower than the rate of step 1 ADP-ribosylation.

\section{Conclusions}

The present study illuminates the distinctive effects of nonribose sugars in the $2^{\prime}-\mathrm{PO}_{4}$ nucleic acid and $\mathrm{NAD}^{+}$substrates on Tpt1 activity. Whereas replacement of each of the ribose sugars flanking the internal $2^{\prime}-\mathrm{PO}_{4}$ with a deoxynucleotide did not affect the efficiency of $2^{\prime}-\mathrm{PO}_{4}$ removal by Runella Tpt1, their replacement with 2'-fluoroarabinose reduced Tpt1 specific activity, albeit without accumulation of the 2'-phospho-ADP-ribosylated intermediate. In contrast, replacing the ribose of the $2^{\prime}-\mathrm{PO}_{4}$ nucleotide with arabinose selectively and severely reduced the rate of the transesterification step and thereby resulted in the buildup of very high levels of the reaction intermediate during catalysis by Runella and Clostridium Tpt1. Replacing the NMN ribose of $\mathrm{NAD}^{+}$with 2'-fluoroarabinose (which eliminates the step 2 ADP-ribose O2" nucleophile) results in trapping of RNA-2'-phospho-(ADP-fluoroarabinose) as a dead-end step 1 product. We find that Tpt1 orthologs differ in their ability to use ara-2" $F-N A D^{+}$.

Our identification of substrate analogs that trap the ADP-ribosylated intermediate has implications for the development of Tpt1 "poisons" as anti-fungals. A poison elicits the formation of a reaction intermediate that is potentially more deleterious (in this case by virtue of the large bulk of 2'-phospho-ADP ribose at the splice junction compared to the 2'-phosphate) than an inhibitor that results in the mere accumulation of 2'-phosphate substrate. Indeed, DNA topoisomerase poisons that trap covalent topoisomerase-DNA intermediates are among the most successful and widely used anti-bacterial and anti-cancer agents in clinical practice (Pommier 2013).

\section{MATERIALS AND METHODS}

\section{Recombinant Tpt1 proteins}

Tpt1 enzymes from Clostridium thermocellum, Homo sapiens, Runella slithyformis, and Chaetomium thermophilum were produced in E. coli and purified as described previously (Munir et al. 2018a,b).

\section{Solid-phase synthesis of oligonucleotides with internal 2'-phosphates}

\section{General methods}

Oligonucleotide syntheses were carried out using an $A B I$ 3400 DNA synthesizer (Applied Biosystems) on a Unylinker (ChemGenes) solid support at a $1 \mu \mathrm{mol}$ scale. Conventional
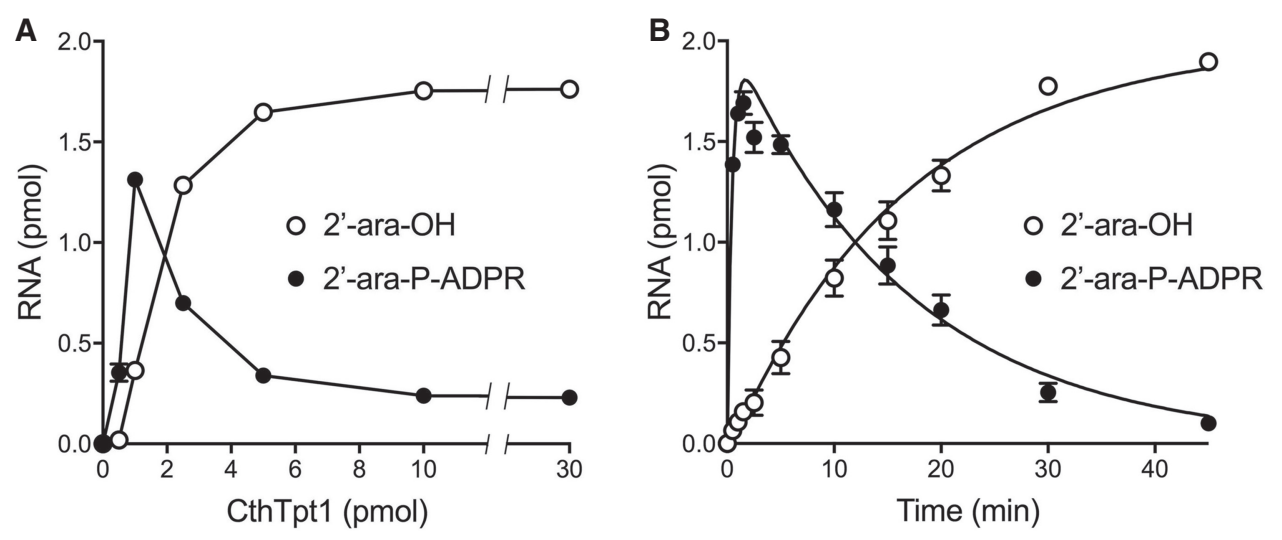

FIGURE 5. Effect of an arabinose-2'- $-\mathrm{PO}_{4}$ on Clostridium Tpt1. (A) Reaction mixtures (10 $\left.\mu \mathrm{L}\right)$ containing $100 \mathrm{mM}$ Tris- $\mathrm{HCl}, \mathrm{pH} 7.5,1 \mathrm{mM} \mathrm{NAD}+0.2$ $\mu \mathrm{M}(2 \mathrm{pmol}) 5^{\prime}{ }^{32} \mathrm{P}$-labeled 6-mer ara-2'- $\mathrm{PO}_{4}$ substrate, and $0,0.5,1,2.5,5,10$, or 30 pmol Clostridium thermocellum (Cth) Tpt1were incubated at $37^{\circ} \mathrm{C}$ for $30 \mathrm{~min}$. (B) A reaction mixture $(100 \mu \mathrm{L})$ containing $100 \mathrm{mM}$ Tris- $\mathrm{HCl}, \mathrm{pH} 7.5,1 \mathrm{mM} \mathrm{NAD}{ }^{+}, 0.2 \mu \mathrm{M} \mathrm{5}^{\prime}{ }^{32} \mathrm{P}-$ labeled 6-mer ara-2'-PO ${ }_{4}$ substrate, and $1 \mu \mathrm{M}$ wild-type CthTpt1 was incubated at $37^{\circ} \mathrm{C}$. The reaction was initiated by adding enzyme to a prewarmed reaction mixture. Aliquots ( $10 \mu \mathrm{L}$, containing $2 \mathrm{pmol}$ of RNA) were withdrawn at the times specified and quenched immediately with 3 volumes of cold $90 \%$ formamide, $50 \mathrm{mM}$ EDTA. The reaction products were analyzed by urea-PAGE and quantified by scanning the gels. The extents of formation of the 2 '$\mathrm{OH}$ product and the ADP-ribosylated intermediate are plotted as a function of input CthTpt1 (panel A) or reaction time (panel B). Each datum is the average of three independent titration or time-course experiments $( \pm S E M)$. 
deoxyribonucleoside, $2^{\prime}$-tert-butyl-dimethylsilyl (TBDMS) ribonucleoside, 2'-fluoro-arabinonucleoside (2'-FANA) and 2'-acetyl levulinyl (ALE) ribonucleoside phosphoramidites (0.15 $\mathrm{M}$ in $\mathrm{MeCN}$ ) (ChemGenes) were used. Additionally, 2'-arabino levulinyl (Lev) phosphoramidite was synthesized as described previously (Katolik et al. 2014). For phosphitylation, bis-cyanoethyl,- $N$, $\mathrm{N}$-diisopropyl-phosphoramidite (0.20 in $\mathrm{MeCN})$ was used. Phosphoramidites were dissolved in $\mathrm{MeCN}$ and activated with 5-ethylthio-1 $\mathrm{H}$-tetrazole ( $0.25 \mathrm{M}$ in $\mathrm{MeCN})$. Capping was carried out by the simultaneous delivery of acetic anhydride in pyridine/ THF and N-methylimidazole (16\% in THF) and contacting the solid support for $6 \mathrm{sec}$. Oxidation of the phosphite triester intermediates was effected with $0.1 \mathrm{M}$ iodine in pyridine/ $\mathrm{H}_{2} \mathrm{O} / \mathrm{THF}(20$ sec); a solution of $3 \%$ trichloroacetic acid in THF, delivered over $1.8 \mathrm{~min}$, was used to deprotect DMTr groups. For 2'-phosphate-containing substrates, a solution of anhydrous TEA/ MeCN (2:3 v/v) was used to remove cyanoethyl phosphate protecting groups, while a $0.5 \mathrm{M}$ solution of hydrazine hydrate in pyridine/AcOH (3:2 v/v) was used to remove ALE protecting groups. All oligonucleotides were deprotected and cleaved from the solid support using an ammonium hydroxide and ethanol solution. TBDMS groups were removed using TREAT-HF. Crude oligonucleotides were purified via HPLC and characterized by LC-MS.

\section{Synthesis of $2^{\prime}$ phosphate-containing oligonucleotides}

Synthesis of RNA sequences containing 2'-phosphate moieties was carried out as previously described (Munir et al. 2018a). The equivalent sequences containing DNA or 2'-FANA at positions flanking the 2'-phosphate RNA branchpoint were also synthesized in this manner using DNA or 2'-FANA phosphoramidites, respectively. For the arabinose-2'-phosphate (ANA 2'-PO ${ }_{4}$ )containing sequence: $5^{\prime}-\mathrm{rCrCrAaraA} \mathrm{A}^{\left(2^{\prime}-\mathrm{P}\right)} \mathrm{rArU}-3^{\prime}$, the first section of the oligonucleotide: $5^{\prime}$-araA ${ }^{\left(2^{\prime}-\text { Lev }\right)} \mathrm{rArU}-3^{\prime}$, was synthesized on the solid support in the conventional $3^{\prime}$ to $5^{\prime}$ solid phase synthesis. The $\operatorname{araA}^{2^{\prime}-\text { Lev }}$ unit in this sequence was introduced by coupling a 5'-DMTr-2'-O-Lev-3'-OCE arabinose phosphoramidite (0.15 M in $\mathrm{MeCN}$ ) for $15 \mathrm{~min}$. In the case of arabinonucleosides, the removal of the backbone cyanoethyl phosphodiester protecting groups is not necessary, since the trans orientation of the free $2^{\prime}-\mathrm{OH}$ to the $3^{\prime}$-phosphate triester will prevent chain cleavage at the arabinose position. To remove the 2'-ALE groups, the columns were returned to the synthesizer and a freshly prepared solution of $0.5 \mathrm{M}$ hydrazine hydrate in pyridine/AcOH $(3: 2 \mathrm{v} / \mathrm{v})$ was flowed through the columns (20 sec flow $+3.75 \mathrm{~min}$ sleep, repeated $4 \times$ ). After washing (MeCN, $10 \mathrm{~min}$ ) and drying (Ar gas, $10 \mathrm{~min}$ ), the solid supports were dried again in vacuo (30 min). To phosphitylate at the newly exposed 2'-OH, bis-cyanoethyl- $\mathrm{N}, \mathrm{N}$-diisopropyl CED phosphoramidite $(0.20 \mathrm{M}$ in $\mathrm{MeCN})$ was coupled for $30 \mathrm{~min}$, and then further oxidized using $0.1 \mathrm{M}$ iodine in pyridine/ $\mathrm{H}_{2} \mathrm{O} / \mathrm{THF}$ (20 sec). To complete the oligonucleotide, standard $3^{\prime}$ to $5^{\prime}$ synthesis was continued on the $5^{\prime}$ terminus of the growing oligonucleotide using the sequence $5^{\prime} \mathrm{rCrCrA}-3^{\prime}$ to yield the desired hexamer oligonucleotide substrate.

Deprotection and cleavage of oligonucleotides from the solid support was achieved by treatment with $1 \mathrm{~mL}$ of cold $29 \%$ aqueous ammonia/ethanol (3:1 v/v) for RNA and 2'-FANA oligonucleotides, and $1 \mathrm{~mL}$ of cold $29 \%$ aqueous ammonia for DNA oligonucleotides for $16 \mathrm{~h}$ at $65^{\circ} \mathrm{C}$. Samples were centrifuged and the supernatant was transferred to a clean $1.5 \mathrm{~mL}$ eppendorf tube and vented for 30 min, chilled on dry ice, and evaporated to dryness. Removal of the 2'-silyl protecting groups for the RNA oligonucleotides was achieved by treatment with a $300 \mu \mathrm{L}$ solution of NMP/Et ${ }_{3} \mathrm{~N} / \mathrm{TREAT}-\mathrm{HF}(3: 4: 6 \mathrm{v} / \mathrm{v} / \mathrm{v})$ for $90 \mathrm{~min}$ at $65^{\circ} \mathrm{C}$, followed by quenching with $3 \mathrm{M} \mathrm{NaOAc}$ buffer $(50 \mu \mathrm{L} ; \mathrm{pH} 5.5)$ and precipitation of the crude oligonucleotide from cold butanol $(1 \mathrm{~mL}$, $-20^{\circ} \mathrm{C}$ ). Samples were chilled on dry ice for $30 \mathrm{~min}$ and then centrifuged. After removing the supernatant, the remaining pellet (containing oligonucleotide) was evaporated to dryness, taken up in autoclaved milliQ water $(1 \mathrm{~mL})$, filtered, and quantified by UV spectroscopy.

Crude oligonucleotides were HPLC-purified using a Waters Protein-Pak DEAE 5PW anion exchange column $(21.5 \times 150$ $\mathrm{mm}$ ). A mobile phase of $1 \mathrm{M}$ aqueous $\mathrm{LiClO}_{4}$ in milli-Q water was used for analysis and purification $\left(0 \%-20 \% \mathrm{LiClO}_{4}\right.$ over $30 \mathrm{~min}, 4 \mathrm{~mL} / \mathrm{min}, 60^{\circ} \mathrm{C}$ ). Following collection of the desired peaks, fractions were combined and excess $\mathrm{LiClO}_{4}$ salts were removed using Gel Pak 2.5 size exclusion columns (Glen Research). Purified oligonucleotides were characterized by electrospray ionizationmass spectrometry (the HPLC elution profiles and MS analyses are shown in Supplemental Figs. S2-S4) and quantified by UV spectroscopy. Extinction coefficients were determined using the IDT OligoAnalyzer tool (www.idtdna.com/analyzer/Applications/ OligoAnalyzer). The oligonucleotides were stored at $-20^{\circ} \mathrm{C}$.

\section{$5^{\prime 32}$ P-labeled oligonucleotide substrates}

Synthetic 6-mer oligonucleotides $5^{\prime}-C C A A^{2^{\prime} P} A U$ containing an internal $2^{\prime}-\mathrm{PO}_{4}$ were $5^{\prime}{ }^{32} \mathrm{P}$-labeled by reaction with phosphatasedead T4 polynucleotide kinase (Pnkp-D167N) in the presence of $\left[\gamma^{32}\right.$ P $]$ ATP. The reactions were quenched with $90 \%$ formamide, $50 \mathrm{mM}$ EDTA, $0.01 \%$ xylene cyanol and the radiolabeled RNAs were purified by electrophoresis through a $40-\mathrm{cm} 20 \%$ polyacrylamide gel containing $7 \mathrm{M}$ urea in $45 \mathrm{mM}$ Tris-borate, $1 \mathrm{mM}$ EDTA. The radiolabeled oligonucleotides were eluted from excised gel slices, recovered by ethanol precipitation, and resuspended in $10 \mathrm{mM}$ Tris- $\mathrm{HCl}, \mathrm{pH} 6.8,1 \mathrm{mM}$ EDTA, and stored at $-20^{\circ} \mathrm{C}$.

\section{Assay of Tpt1 activity}

Reaction mixtures containing $100 \mathrm{mM}$ Tris- $\mathrm{HCl}(\mathrm{pH} 7.5), 0.2 \mu \mathrm{M}$ $5^{\prime 32} \mathrm{P}$-labeled nucleic acid substrates, $\mathrm{NAD}^{+}$or ara- $2^{\prime \prime} \mathrm{F}-\mathrm{NAD}^{+}$as specified, and Tpt1 as specified in the figure legends were incubated at $37^{\circ} \mathrm{C}$. The reactions were quenched at the times specified in the figure legends by addition of 3 volumes of cold $90 \%$ formamide, $50 \mathrm{mM}$ EDTA. The products were analyzed by electrophoresis (at $55 \mathrm{~W}$ constant power) through a 40-cm 20\% polyacrylamide gel containing $7 \mathrm{M}$ urea in $45 \mathrm{mM}$ Tris-borate, $1 \mathrm{mM}$ EDTA and visualized by autoradiography and/or scanning the gel with a Fujifilm FLA-7000 imaging device. The products were quantified by analysis of the gel scans in ImageQuant. Ara$2^{\prime \prime} \mathrm{F}_{-N A D}{ }^{+}$was purchased from BIOLOG (Bremen, Germany; Cat. No. D148).

\section{SUPPLEMENTAL MATERIAL}

Supplemental material is available for this article. 


\section{ACKNOWLEDGMENTS}

This work was supported by grants from the U.S. National Institutes of Health, National Institute of General Medical Sciences (R35-GM126945) and the National Science and Engineering Research Council of Canada (Discovery grant to M.J.D.).

Received December 17, 2019; accepted January 10, 2020.

\section{REFERENCES}

Banerjee A, Munir A, Abdullahu L, Damha MJ, Goldgur Y, Shuman S. 2019. Structure of tRNA splicing enzyme Tpt1 illuminates the mechanism of RNA 2'-PO recognition and ADP-ribosylation. Nat Commun 10: 218. doi:10.1038/s41467-018-08211-9

Chan CM, Zhou C, Huang R. 2009. Reconstituting bacterial RNA repair and modification in vitro. Science 326: 247. doi:10.1126/sci ence. 1179480

Culver GM, McCraith SM, Zillman M, Kierzek R, Michaud N, LaReau RD, Turner DH, Phizicky EM. 1993. An NAD derivative produced during transfer RNA splicing: ADP-ribose 1"-2" cyclic phosphate. Science 261: 206-208. doi:10.1126/science.8392224

Culver GM, McCraith SM, Consaul SA, Stanford DR, Phizicky EM. 1997. A 2'-phosphotransferase implicated in tRNA splicing is essential in Saccharomyces cerevisiae. J Biol Chem 272: 1320313210. doi:10.1074/jbc.272.20.13203

Damha MJ, Wilds C, Noronha AM, Brukner I, Borkow G, Parniak MA. 1998. Hybrids of RNA and arabinonucleic acids (ANA and 2'FANA) are substrates of ribonuclease $\mathrm{H}$. J Am Chem Soc 120: 12976-12977. doi:10.1021/ja982325+

Harding HP, Lackey JG, Hsu HC, Zhang Y, Deng J, Xu RM, Damha MJ, Ron D. 2008. An intact unfolded protein response in Trpt1 knockout mice reveals phylogenic divergence in pathways for RNA ligation. RNA 14: 225-232. doi:10.1261/rna.859908

Jain R, Shuman S. 2011. Active site mapping and substrate specificity of bacterial Hen1, a manganese-dependent $3^{\prime}$ terminal RNA ribose 2'O-methyltransferase. RNA 17: 429-438. doi:10.1261/rna .2500711

Kalota A, Karabon L, Swider C, Viazovkina E, Elzagheid M, Damha MJ, Gewirtz A. 2006. 2'-deoxy-2'-fluoro- $\beta$-D-arabinonucleic acid (2'FANA) modified oligonucleotides (ON) effect highly efficient, and persistent, gene silencing. Nucleic Acids Res 34: 451-461. doi:10.1093/nar/gkj455

Katolik A, Johnsson R, Montemayor E, Lackey JG, Hart PJ, Damha MJ. 2014. Regiospecific solid-phase synthesis of branched oligoribonucleotides that mimic intronic lariat RNA intermediates. J Org Chem 79: 963-975. doi:10.1021/jo4024182

Liu Q, Graeff R, Kriksunov IA, Jiang H, Zhang B, Oppenheimer N, Lin H, Potter BV, Lee HC, Hao Q. 2009. Structural basis for enzymatic evolution from a dedicated ADP-ribosyl cyclase to a multifunctional NAD hydrolase. J Biol Chem 284: 27637-27645. doi:10.1074/jbc.M109.031005

Martín-Pintado N, Yahyaee-Anzahaee $M$, Campos-Olivas $R$, Noronha AM, Wilds CJ, Damha MJ, González C. 2012. The solu- tion structure of double helical arabino-nucleic acids (ANA and 2'F-ANA): effect of arabinoses in duplex-hairpin interconversion. Nucleic Acids Res 40: 9329-9339. doi:10.1093/nar/gks672

McCraith SM, Phizicky EM. 1991. An enzyme from Saccharomyces cerevisiae uses $\mathrm{NAD}^{+}$to transfer the splice junction $2^{\prime}$-phosphate from ligated tRNA to an acceptor molecule. J Biol Chem 266: 11986-11992.

Munir A, Abdullahu L, Damha MJ, Shuman S. 2018a. Two-step mechanism and step-arrest mutants of Runella slithyformis NAD ${ }^{+}$-dependent tRNA 2'-phosphotransferase Tpt1. RNA 24: 1144-1157. doi:10.1261/rna.067165.118

Munir A, Banerjee A, Shuman S. 2018b. NAD+-dependent synthesis of a 5'-phospho-ADP-ribosylated RNA/DNA cap by RNA 2'-phosphotransferase Tpt1. Nucleic Acids Res 46: 9617-9624. doi:10 $.1093 /$ nar/gky792

Munir A, Abdullahu L, Banerjee A, Damha MJ, Shuman S. 2019. $\mathrm{NAD}^{+}$-dependent RNA terminal $2^{\prime}$ and $3^{\prime}$ phosphomonoesterase activity of a sub-set of Tpt1 enzymes. RNA 25: 783-792. doi:10 $.1261 /$ rna.071142.119

Nandakumar J, Shuman S. 2004. How an RNA ligase discriminates RNA damage versus DNA damage. Mol Cell 16: 211-221. doi:10.1016/j.molcel.2004.09.022

Pommier Y. 2013. Drugging topoisomerases: lessons and challenges. ACS Chem Biol 8: 82-95. doi:10.1021/cb300648v

Popow J, Schlieffer A, Martinez J. 2012. Diversity and roles of (t)RNA ligases. Cell Mol Life Sci 69: 2657-2670. doi:10.1007/s00018-0120944-2

Remus BS, Shuman S. 2014. Distinctive kinetics and substrate specificities of plant and fungal tRNA ligases. RNA 20: 462-473. doi:10 $.1261 /$ rna.043752.113

Sawaya R, Schwer B, Shuman S. 2005. Structure-function analysis of the yeast $N A D^{+}$-dependent tRNA 2'-phosphotransferase Tpt1. RNA 11: 107-113. doi:10.1261/rna.7193705

Segal ES, Gritsenko V, Levitan A, Yadav B, Dror N, Steenwyk JL, Silberberg Y, Meilich K, Rokas A, Gow NA, et al. 2018. Gene essentiality analyzed by in vivo transposon mutagenesis and machine learning in a stable haploid isolate of Candida albicans. mBio 9: e02048-18. doi:10.1128/mBio.02048-18

Spinelli SL, Malik HS, Consaul SA, Phizicky EM. 1998. A functional homolog of a yeast tRNA splicing enzyme is conserved in higher eukaryotes and in Escherichia coli. Proc Natl Acad Sci 95: 1413614141. doi:10.1073/pnas.95.24.14136

Spinelli SL, Kierzek R, Turner DH, Phizicky EM. 1999. Transient ADPribosylation of a 2'-phosphate implicated in its removal from ligated tRNA during splicing in yeast. J Biol Chem 274: 2637-2644. doi:10.1074/jbc.274.5.2637

Steiger MA, Jackman JE, Phizicky EM. 2005. Analysis of 2'-phosphotransferase (Tpt1p) from Saccharomyces cerevisiae: evidence for a conserved two-step reaction mechanism. RNA 11: 99-106. doi:10 $.1261 /$ rna.7194605

Wilds CJ, Damha MJ. 2000. 2'-Deoxy-2'-fluoro- $\beta$-D-arabinonucleosides and oligonucleotides (2'F-ANA): synthesis and physicochemical studies. Nucleic Acids Res 28: 3625-3635. doi:10 $.1093 /$ nar/28.18.3625 

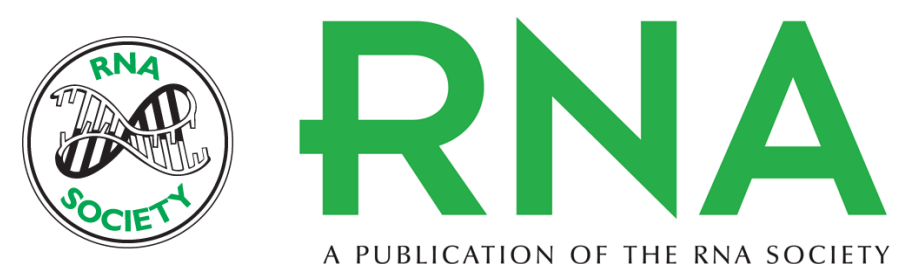

A PUBLICATION OF THE RNA SOCIETY

\section{Substrate analogs that trap the 2'-phospho-ADP-ribosylated RNA intermediate of the Tpt1 (tRNA 2 '-phosphotransferase) reaction pathway}

Swathi Dantuluri, Leonora Abdullahu, Annum Munir, et al.

RNA 2020 26: 373-381 originally published online January 13, 2020

Access the most recent version at doi:10.1261/rna.074377.119

Supplemental Material

References

Creative Commons License

Email Alerting Service
http://rnajournal.cshlp.org/content/suppl/2020/01/13/rna.074377.119.DC1

This article cites 25 articles, 15 of which can be accessed free at: http://rnajournal.cshlp.org/content/26/4/373.full.html\#ref-list-1

This article is distributed exclusively by the RNA Society for the first 12 months after the full-issue publication date (see http://rnajournal.cshlp.org/site/misc/terms.xhtml). After 12 months, it is available under a Creative Commons License (Attribution-NonCommercial 4.0 International), as described at http://creativecommons.org/licenses/by-nc/4.0/.

Receive free email alerts when new articles cite this article - sign up in the box at the top right corner of the article or click here.

To subscribe to RNA go to:

http://rnajournal.cshlp.org/subscriptions 